University of Nebraska - Lincoln

DigitalCommons@University of Nebraska - Lincoln

Faculty Publications, Classics and Religious

Studies Department

September 1998

\title{
LADY WISDOM AND DAME FOLLY AT QUMRAN
}

Sidnie White Crawford

University of Nebraska-Lincoln, scrawford1@unl.edu

Follow this and additional works at: https://digitalcommons.unl.edu/classicsfacpub

Part of the Classics Commons

Crawford, Sidnie White, "LADY WISDOM AND DAME FOLLY AT QUMRAN" (1998). Faculty Publications, Classics and Religious Studies Department. 23.

https://digitalcommons.unl.edu/classicsfacpub/23

This Article is brought to you for free and open access by the Classics and Religious Studies at DigitalCommons@University of Nebraska - Lincoln. It has been accepted for inclusion in Faculty Publications, Classics and Religious Studies Department by an authorized administrator of DigitalCommons@University of Nebraska - Lincoln. 


\title{
LADY WISDOM AND DAME FOLLY AT QUMRAN
}

\author{
SIDNIE WHITE CRAWFORD \\ University of Nebraska-Lincoln*
}

The female figures of Lady Wisdom and Dame Folly, found in the postexilic Wisdom literature, have always attracted much debate and speculation. The questions of who they are and what they stand for, particularly in the case of Lady Wisdom, have been hotly debated. Is she merely a literary creation, driven by the fact that the nouns for wisdom in Hebrew and Greek, חכמה and бopía, are feminine in gender? Or is she an actual divine figure, a female hypostasis of Yahweh, the god of Israel, indicating a female divine presence in Israelite religion? These debates have yet to be resolved. Now that the large corpus of sapiential texts from Qumran is beginning to be studied, new light may be shed on the figures of Lady Wisdom and Dame Folly. This paper investigates these two figures in three Qumran texts: 4Q184, "The Wiles of the Wicked Woman," 4Q185, "A Sapiential Work," and 4Q525, "Beatitudes," to see whether the presentation of these figures in three otherwise unknown texts can shed any light on their function in Second Temple Jewish thought. First, I will begin with a brief overview of the wisdom texts containing these two figures, starting with the biblical evidence.

\section{Hebrew Bible}

Lady Wisdom, or Wisdom personified as a female figure, appears in one canonical wisdom text, the book of Proverbs. Wisdom also appears in the book of Job, but less as a personified figure and more as an abstract concept. Both books are generally considered to be post-exilic, and both are found

\footnotetext{
* It gives me great pleasure to dedicate this article to Eugene C. Ulrich, who has for many years been my mentor, colleague and friend. Professor Ulrich's distinguished work as editor of the biblical texts from Qumran has shaped a generation of biblical and Qumran studies, and all who work in the field constantly find themselves indebted to him.
} 
at Qumran. The parade text for the figure of Lady Wisdom is Proverbs 1-9, where she appears in three major pericopes: $1: 20-33 ; 8: 1-36$, and 9:1-6, 10-12. In these pericopes, Wisdom speaks for herself, on her own authority. Her primary relationship is with God, since she is the first thing created by God, and she is with God during the entire act of creation. However, her chief delight and focus is men, to whom she constantly calls. It is through her that men are able to attain knowledge of God and the good life (3:13-18). ${ }^{1}$ In Wisdom's main speech in chapter 8 , she claims that she was created by God before the cosmos, dwells with God, and participated with, or at least observed, God in the creation of the world. All these attributes make her status as a divine being, at least in Proverbs 1-9, seem unquestionable. $^{2}$

Her opposite number, Dame Folly (אשח כםילוח), is, however, clearly human. She is identified with the "strange woman" (אשה זרה כשילה), the adulteress whose purpose is to lead the young man astray (the androcentric nature of the text here should not require comment). She is also the "foreign" woman (נכדיה), who, like many foreign women in the Israelite tradition, leads men from the right (Israelite) path. ${ }^{3}$ The most interesting thing to note about the portrayal of Folly is that, while Wisdom's gifts cover all aspects of life (e.g. riches, insight, a life of ease), Folly's snares are almost entirely sexual (a telling comment on male fears of female temptation). This is in spite of the fact that other parts of Proverbs 1-9 mention other types of wicked or foolish behavior (e.g. theft, lying, murder, haughtiness; cf. 1:11-19; 4:24;

${ }^{1}$ I am using the term "men" advisedly here. As Carol Newsom has convincingly demonstrated, Proverbs 1-9 is written in a male voice to a male audience; women, whether as wisdom or folly, function only as the other against which men measure themselves. C.A. Newsom, "Woman and the Discourse of Patriarchal Wisdom: A Study of Proverbs 1-9," Gender and Difference in Ancient Israel (ed. P. L. Day; Minneapolis: Fortress Press, 1989) 142-60.

${ }^{2}$ Wisdom's attributes and actions can be related to Ancient Near Eastern tutelary gods such as the Sumerians' Nisba and Inanna and the Egyptians' Ma'at and Isis, thus reinforcing her divine status. See C.R. Fontaine, "Proverbs," The Women's Bible Commentary (eds. C. A. Newsom and S. H. Ringe; London: SPCK; Louisville, KY: John Knox/Westminster, 1992) 145-52.

${ }^{3} \mathrm{Cf}$. the condemnation of Solomon in $1 \mathrm{Kgs} 11: 1-8$ for being led astray by his foreign wives. Solomon is, of course, traditionally credited as author of the Book of Proverbs (1:1). For further discussion of the אשה זרה in Proverbs, see G.A. Yee, "I Have Perfumed My Bed with Myrrh: The Foreign Woman ('iššâ zārâa) in Proverbs 1-9," and H. C. Washington, "The Strange Woman (אשה זרה/נכריה) of Proverbs 1-9 and Post-Exilic Judaean Society," A Feminist Companion to Wisdom Literature (ed. A. Brenner: Sheffield: Shefield Academic Press, 1995) 9:110-26, 157-85.
6:12-19). So while Wisdom, the positive female figure, embraces all aspects of human life, Folly, the negative female figure, encompasses only sexual sin. In her two main speeches, 7:10-20 and 9:13-18, her allure is sexual, although the consequences of heeding her are cosmic, leading to "the depths of Sheol," pointing to a dark, chthonic side of Folly. ${ }^{4}$ This is a theme that will recur.

The wisdom poem in Job 28:12-28 is thought by many to be a separate wisdom piece incorporated by the author of Job into his book. In it, wisdom is clearly associated with God, and is said to have been created by God at the time of creation. However, wisdom is not a personified figure here, and no particular feminine characteristics are assigned to it. Interestingly, it is God who shows the way to wisdom, rather than vice-versa. A variation on this theme appears in later apocryphal and pseudepigraphical literature. ${ }^{5}$

\section{Apocrypha and Pseudigrapha}

There are several passages in the apocryphal and pseudepigraphical literature in which the figure of Wisdom appears, and two distinct strands of the understanding of that figure which begin to emerge. These passages draw heavily on Proverbs 1-9, although other influences also appear. The Wisdom of Jesus ben Sira, or Ecclesiasticus, opens with the praise of Wisdom, a female figure, created by God before all other things, and poured out on all flesh (1:1-20). Her manifestation in human beings is the "fear of the Lord," which is the beginning, the fullness, the crown, and the root of Wisdom. In chapter 24, Wisdom describes herself as a divine being, whose home is in the heavens, seeking a dwelling place on earth, among humans. Here the relationship to Wisdom's speech in Proverbs 8 is clear. ${ }^{6}$ Finally, God commands her to dwell with Israel, and this leads Ben Sira to his great declaration, that Wisdom is the Torah, the special possession of Israel: "All this is the book of the covenant of the Most High God, the law that Moses

${ }^{4}$ I would like to thank Carole Fontaine for drawing my attention to this aspect of Folly. See Fontaine, "Proverbs." and also C. Camp, "What's So Strange about the Strange Woman," The Bible and the Politics of Exegesis: Essays in Honor of Norman K. Gottwald on his Sixty-Fifth Birthday (eds. D. Jobling, P. L. Day and G. T. Sheppard: Cleveland: Pilgrim Press, 1991) 31.

For commentary on Job, see, e.g., N. Habel, The Book of Job. A Commentary (OTL; Philadelphia: Westminster Press, 1985).

${ }^{6}$ E.M. Schuller, "The Apocrypha." The Women's Bible Commentary, 237. Wisdom's speech is also similar to the self-laudatory Isis hymns from the Hellenistic period. 
commanded us as an inheritance for the congregations of Jacob" (24:23; see also 15:1). This important theme will recur in other literature. Finally, Sir. 51:13-20 is a poem detailing the author's search for wisdom as a youth; the description of wisdom has erotic overtones $(51: 15)$, but Wisdom's overall characterization is as an abstract concept rather than a personified being. Ben Sira does not mention Folly as a personification of wickedness; however, his book is rife with warnings concerning the dangers of women's sexuality, which he considers ready to burst out and wreak havoc at a moment's notice (e.g. 22:3-6; 25:16-26; 26:7-12). ${ }^{7}$ Ben Sira is found in fragmentary form at Qumran (in Cave 2, but not in Cave 4) and Masada, although ch. 24 has not been found either at Qumran or Masada. Chapter 51 surfaces at Qumran in an unexpected place. in 11QPsalms ${ }^{\mathrm{a}}$ as a free-standing psalm, indicating that before its location in Ben Sira it was a "free-floating" composition. ${ }^{8}$

The Wisdom of Solomon, which is not found at Qumran, also declares that Wisdom is a divine being, present at creation $(7: 22 b-8: 1)$, but the book moves in a completely different direction, heavily influenced by Hellenistic thought. ${ }^{9}$ In the Wisdom of Solomon, Wisdom is an eternal emanation of the deity, both immanent and transcendent, that permeates all creation and makes those who seek her the friends of God. There are also erotic elements in the portrayal of Wisdom, when Solomon seeks to make her his bride and desires "intercourse" ( $\sigma \nu v \alpha v \alpha \sigma \tau \rho \circ \varphi \eta)$ with her (8:2-16). Nowhere, however, does the Wisdom of Solomon equate Wisdom with the Torah. ${ }^{10}$ This portrayal of Wisdom, with its clear Greek overtones, is unique in the Apocrypha and the Pseudepigrapha.

Two other short passages from the Apocrypha and Pseudepigrapha are worth mentioning. The Book of Baruch, 3:9-4:4, which is not found at

${ }^{7}$ For further discussion, see ibid., 237

${ }^{8}$ J. C. VanderKam, The Dead Sea Scrolls Today (Grand Rapids, MI: Eerdmans, 1994) 35-36.

${ }^{9}$ D. Winston, The Wisdom of Solomon (AB 43; Garden City, NY: Doubleday. 1979) 172-90. Winston also points out the parallels in the portrayal of Wisdom to the Isis aretologies of the Hellenistic period, continuing the pattern of analogy to Ancient Near Eastern goddesses.

${ }^{10}$ However, Jack T. Sanders points out that while the Wisdom of Solomon does not equate Wisdom and Torah, it does use the Torah narrative to illustrate its points about Wisdom's capacity to save and protect the one who seeks her (cf. chs 10-11) I would like to thank Professor Sanders for providing me with a copy of his paper "When Sacred Canopies Collide: The Reception of the Torah of Moses in the Wisdom Literature of the Second-Temple Period," presented at the Annual Meeting of the Society of Biblical Literature in 1996.
Qumran, seems to draw on Job 28 and Ben Sira for its portrayal of Wisdom. In Baruch, Wisdom is created by God, sought by humans, and, as in Ben Sira, equated with the Torah of Israel: "She [Wisdom] is the book of the commandments of God, the law that endures forever. All who hold her fast will live, and those who forsake her will die" (4:1). A different interpretation of Wisdom is found in 1 Enoch 42, part of the Similitudes of Enoch (the only section of 1 Enoch not found at Qumran), which utilizes the theme of Wisdom seeking a dwelling among humans and not finding one. However. unlike Ben Sira, Enoch does not go on to say that Wisdom finds its particular dwelling among the people of Israel, and there is no equation of the divine figure of Wisdom with the Torah. ${ }^{11}$ Rather, the figure of Iniquity, or Folly, which appears to be here a divine or semi-divine figure, goes out among humans and finds a dwelling place among them. No more is said about either figure in the Similitudes.

Several themes, therefore, are present in the apocryphal and pseudepigraphical literature which were also noted in the biblical literature: Wisdom as a divine creation, female in gender, with a particular role in creation and a particular relationship with humanity (or, more probably, men). In a separate development, Wisdom also begins to be equated with the Torah as the special possession of Israel. Folly, on the other hand, is still associated almost exclusively with sins having to do with women's sexuality (with the exception of 1 Enoch 42, where she is a more general figure). These themes continue at Qumran.

\section{Qumran Evidence}

The main sources for the figures of Folly and Wisdom at Qumran are the manuscripts 4Q184 and 4Q185, both published by John Allegro in DJD 5 and extensively commented on by John Strugnell. ${ }^{12}$ 4Q184 is perhaps the better known text, for Allegro gave it an intriguing title, "The Wiles of the Wicked Woman," while 4Q185 merely was called "A Sapiential Work." 4Q184 discusses a female figure who can be clearly associated with Dame

${ }^{11} \mathrm{G}$. Nickelsburg suggests that 1 Enoch 42 is a parody of the claim by Ben Sira 34 and Bar. 4:1 that Wisdom is gained by the study of the Torah; for Enoch, Wisdom is accessible only through divine revelation. Jewish Literature Between the Bible and the Mishnah (Philadelphia: Fortress Press, 1981) 216.

12 J.M. Allegro, Qumrân Cave 4.1: (4Q158-4Q186) (DJD 5; Oxford: Clarendon Press, 1968). J. Strugnell, "Notes en marge du volume V des 'Discoveries in the Judaean Desert of Jordan," $\operatorname{RevQ} 7$ (1970) 163-276. 
Folly, while 4Q185 features a female figure who is probably to be equated with Lady Wisdom. Both texts draw heavily on Proverbs 1-9, but they do not appear to utilize the apocryphal and pseudepigraphical texts discussed above. They both exist in single copies and both manuscripts date paleographically, according to Strugnell, to the first century BCE. Since 4Q184's subject, Dame Folly, is beyond doubt, I will begin with that text. ${ }^{13}$ The text begins by introducing a female figure whose every action is sinful:

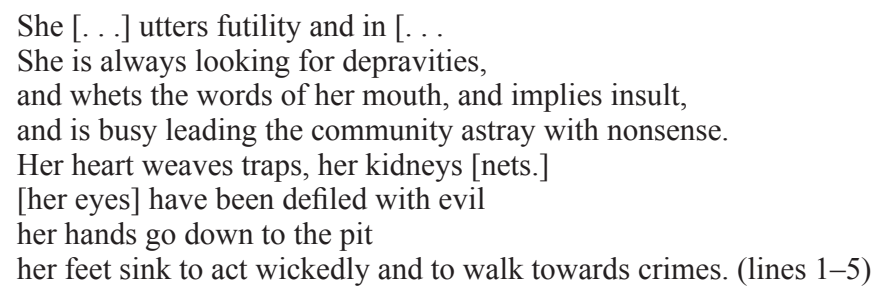

4Q184 is almost a pastiche of allusions to Proverbs 1-9, where Dame Folly's sins are sexual, and only sexual, in nature. Here in 4Q184, her wicked actions also lead to the corruption of men through illicit sexuality: "Her eyes scan hither and yon, and she raises her eyebrows impudently, to spot the just man and overtake him..." (lines 13-14). The idea of the wanton woman speaking "smooth words" (line 17) and leading the simple astray with her sexuality occurs in Prov. $2: 16$; 5:3; 6:24; 7:5, 21; 9:13-18. Her paths as "paths of death" and "tracks to sin" and her gates as the "gates of death" and "entrance to Sheol" (lines 8-11) echo Prov. 2:13-15, 18-19; $5: 5-6 ; 7: 25-27$ and 9:18. The idea that she sits in the city gates, where she entraps men into fornication ("In the city squares she veils herself, and stations herself in the gates of the village, and there is no-one who interrupts her in [her] incessant [fornicating.]"'), is taken directly from Prov. 7:10-12 and 9:13-18, and the notion that she does this to pervert a righteous man is a reversal of the role of Lady Wisdom, who cries out in the city gate in order to set the simple on the path of righteousness (cf. Prov. 1:21-22; 3:23$26 ; 8: 1-5 ; 9: 3-6)$. The sin contemplated here is clearly fornication, as in Proverbs 1-9, and will lead to ruin.

The female figure of 4Q184, however, appears to be more cosmic in scope than the simple "loose woman" of Proverbs 1-9. Her clothing is not merely flashy, as in Prov. 7:10 ("decked out like a prostitute"), but are "shadows

${ }^{13}$ All translations, unless otherwise noted, are taken from F. Garcia Martinez, The Dead Sea Scrolls Translated (trans. W.G.E. Watson; Leiden: E.J. Brill, 1994). of twilight" and "diseases of corruption." Her attire has bat-like "wings" (line 4). Her dwelling is in the "heart of night," the "foundation of gloom," the "tents of silence," and "the eternal fire." One is reminded of the various divine beings associated with death in the Ancient Near East: the Canaanite god Môt, whose residence is referred to as "Muck" and "Phlegm," Ereshkigal, queen of the Mesopotamian underworld, where the goddess Inanna is turned into a rotting piece of meat hung on a hook, and perhaps most especially, the winged night demon Lilith who appears, for example, in Isa. 34:14 as an inhabitant of a destroyed Edom, a "land of burning pitch." Lilith goes on to a spectacular career in Hebrew folklore, and in most tales, her sin is sexual; she refuses, in one way or another, to be a proper wife to Adam, and so is driven out of Paradise; she now preys on innocent men and on women in childbirth. ${ }^{14}$ All of these figures are associated in mythology with cosmic disorder; their counterparts (Ba'l, Inanna, Eve) are associated with the proper divine order of the world. Thus, the Wicked Woman in 4Q184 becomes the personification of chaos opposed to God's established order. ${ }^{15}$ The chthonic qualities of Dame Folly, hinted at in Proverbs, become clear in 4Q184. In fact, as Baumgarten notes, "most pronounced is the emphasis on her association with the netherworld." 16 Dame Folly has ceased to be simply human and has become demonic.

This "catastrophization" of Dame Folly may be similar to the cosmological struggle between good and evil that one finds in some Qumran sectarian literature, particularly the doctrine of the Two Spirits in the Community Rule, cols 3 and 4. The Spirit of Darkness, in that text, leads those who walk in its way (characterized as "paths of darkness") into, among other things, "impudent enthusiasm, appalling acts performed in a lustful passion, and filthy paths for indecent purposes." Those who follow the Spirit of Darkness will end, like those enticed by the Wicked Woman, in the netherworld, "with the humiliation of destruction by the fire of the dark regions."17 Thus sin, for the Qumran community, is not simply human frailty, but part

${ }^{14}$ For a fuller discussion of this and other demonic figures and a complete bibliography, see J.M. Baumgarten. "On the Nature of the Seductress in 4Q184." RevQ 15 (1991) 133-43.

${ }^{15}$ R. D. Moore, "Personification of the Seduction of Evil: 'The Wiles of the Wicked Woman'," RevQ 10 (1979-81) 512.

${ }^{16}$ Baumgarten, "On the Nature," 137.

${ }^{17}$ A major factor in the doctrine of the Two Spirits found in the Community Rule is the idea of individual predestination, a notion that does not occur in the texts so far investigated. Rather, each individual is free to choose his own path. 
of the cosmic struggle between God and Satan. This may account for the "more-than-human" quality of the Wicked Woman/Dame Folly in 4Q184. ${ }^{18}$

References to Lady Wisdom are less clear in the Qumran sapiential texts, given the fragmentary nature of that material. She seems to appear in a second text published by Allegro in DJD 5, 4Q185. 4Q185 is a somewhat longer work than 4Q184, with three columns of text preserved. The portion relevant to our concerns comes from 2:8-15.

Blessed is the man to whom she has been given, the son of man [. .

The wicked person should not brag, saying:

She has not been given to me and I [shall not look for her.]

[God has given her] to Israel, and like a good gift, gives her.

He has saved all his people, but has destroyed...

Whoever glories in her will say:

he shall take possession of her and find her. (lines 8-12)

The figure in question appears to be a personified female figure, given by God, sought (or not sought) by men, whose possession gives the good life. Once again, the text is a pastiche of allusions to biblical texts. Compare, for example, Prov. 3:13-18:

Happy are those who find wisdom, and those who get understanding, for her income is better than silver, and her revenue better than gold. She is more precious than jewels, and nothing you desire can compare with her. Long life is in her right hand; in her left hand are riches and honor. Her ways are ways of pleasantness, and all her paths are peace. She is a tree of life to those who lay hold of her; those who hold her fast are called happy.

with lines 11-14:

Whoever glories in her will say:

he shall take possession of her and find her, and get her as an inheritance.

With her there are long days, and greasy bones, and a happy heart, riches and honor.

Her youth [increases] favours and salvation.

Blessed the man who does it [her], and does not [. .

and does not look for her with a fraudulent spirit,

or grow fond of her with flattery.

Further, the idea that wisdom is something that is passed on from parents to children is prevalent in wisdom literature (e.g., Sir. 4:16: "If they

${ }^{18}$ However, it should be noted that this "demonization" is part of a larger pattern of the continuing denigration of human women in some of the Wisdom literature of the post-exilic period, from Dame Folly in Proverbs 1-9, through the human women who cause Ben Sira such misgivings. to Qohelet, who, in spite of his best efforts, cannot find any woman who is wise (7:28)! remain faithful, they will inherit her; their descendants will also obtain her."), and appears in 4Q185, 2: 14-15 as well:

As it was given to their fathers so will he inherit her.

[He will grow fond of her] with all force of his strength and with all his vigour without restraint.

And he will give her in inheritance to his descendants.

However, unlike the active female figure found in Proverbs, this figure is an object, not a subject; she is given by God, sought by humans, and possession of her brings rewards, but, at least in the material we have, she does not act. In fact, she more closely resembles the non-personified figure of Wisdom in Job 28, where Wisdom is described as established by God, but is not active, or Bar. 3:9-4:4, where Wisdom is essentially passive and, importantly, is given by God to Israel ("He found the whole way to knowledge, and gave her to his servant Jacob and to Israel, whom he loved." 3:36). ${ }^{19}$ The notion that Wisdom is a special gift from God to Israel is also prominent in Sir. 24:8, 10-12:

Then the Creator of all things gave me a command, and my Creator chose the place for my tent. He said, "Make your dwelling in Jacob, and in Israel receive your inheritance.” In the holy tent I ministered before him, and so I was established in Zion. Thus in the beloved city he gave me a resting place. and in Jerusalem was my domain. I took root in an honored people, in the portion of the Lord, his heritage.

Here, of course, Wisdom is a far more active figure; however, the result is the same: Wisdom becomes the special possession of the people of Israel. This raises the question of whether Wisdom is being equated with the Torah in 4Q185, as in Ben Sira and Baruch. A case can certainly be made for that contention. Wisdom is given specifically to Israel; she is inherited from the fathers and passed on to the descendants; possession of her brings blessing, and she is to be loved by the possessor; and, in line 13, we find the admonition, "Blessed the man who does it [her], and does not [ . . ." "Doing" wisdom can certainly be understood as following the Law, and this seems to be the best understanding of the female figure in this text Thus, in 4Q185, we find the same movement toward equating wisdom with the Torah that we found in Ben Sira and Baruch.

One other text from Qumran also contains mention of a female Wisdom figure, although the referent is not as clearly personified as in $4 \mathrm{Q} 185$.

${ }^{19}$ Sanders, "When Sacred Canopies Collide," 5, again notes that 4Q185 also uses the Torah to illustrate its concept of Wisdom. 
4Q525 (= 4QBeatitudes), which exists in only one copy (like 4Q184 and $185)$, is dated by its editor, Émile Puech, to c. 200 BCE. ${ }^{20}$ The type of literature to which 4QBeatitudes belongs is Wisdom, since it contains, as de Roo notes, "striking resemblance[s] between 4Q525 and traditional Jewish Wisdom books such as Proverbs and Ben Sira." ${ }^{21}$ However, as George Brooke has observed, 4QBeatitudes also contains eschatological language, which represents a change from Proverbs and Ben Sira, and places 4Q525 in relationship with 4Q184's cosmic description of the Wicked Woman. ${ }^{22}$ The passages that mention the figure of Wisdom are, first, frag. 2 ii 2-7:
Blessed are those who rejoice in her
and do not explore insane paths.
Blessed are those who search for her with pure hands.
and do not importune her with a treacherous heart.
Blessed is the man who attains Wisdom.
and walks in the law of the Most High.
and dedicates his heart to her ways,
and is constrained by her discipline
and always takes pleasure in her punishments;
and does not forsake her in the hardship of [his] wrongs,
and in the time of anguish does not discard her,
and does not forget her [in the days of] terror,
and in the distress of his soul does not loathe her.
For he always thinks of her,
and in his distress he meditates on [the law.
[and throughout] his [whole] life [he thinks] of her,
[and places her] in front of his eyes
in order not to walk on paths [of evil ...]

Frag. 2 iii:

She cannot be obtained with gold

with any precious stone $\left[\ldots{ }^{23}\right.$

And frag. 4 6-11

do n]ot seek her with [wiclked heart [ . .

Do $n]$ ot se[ek her] with arrogant heart [ . .

${ }^{20}$ É. Puech, "The Collection of Beatitudes in Hebrew and in Greek (4Q525 1-4 and MT 5.3-12)" Early Christianity in Context. Monuments and Documents (eds F. Manns and E. Alliata: Studium Biblicum Franciscanum: Collectio Maior 38; Jerusalem: Franciscan Printing Press, 1993) 356.

${ }^{21}$ J.C.R. de Roo, "Is 4Q525 a Qumran Sectarian Document." The Scrolls and the Scriptures: Qumran Fifty Years After (eds S.E. Porter and C.A. Evans: Sheffield: Sheffield Academic Press, 1997) 345.

${ }^{22}$ G.J. Brooke, "The Wisdom of Matthew's Beatitudes (4QBeat and Mt. 5:312)," Scripture Bulletin 19 (1988-1989) 37.

${ }^{23}$ Compare with Prov. 3:15.
Do not] abandon [your inh]eritance to the na[tions.]

or your lot to the sons of foreigners.

for, the wise $[\operatorname{man} .$.

they instruct with tenderness

Those who fear God keep her paths and walk in her laws,

and do not reject her reproaches.

Those who understand will acquire $[$. .

Those who walk in perfection keep away from evi

and do not reject her admonishments [ . . .

In these passages Wisdom, which men seek, is unquestionably equated with the Torah, most clearly in 2 ii 3-4, where the parallelism demands the equation: "Blessed is the man who attains Wisdom, and walks in the law of the Most High." ${ }^{24}$ Wisdom/Torah, according to frag. 2. should be followed and meditated on in order to obtain blessing (lines 12-13). Wisdom Torah is the special inheritance of Israel, the "special path" for those who love and fear God. Thus, Wisdom has lost the special status we observed in Proverbs 1-9, Job 28, 1 Enoch 42, and the Wisdom of Solomon, and become subsumed under the Torah, as in Sir. 15:1, 24:23 and Bar. 4:1. This equation of Wisdom and Torah in 4Q525 and, probably, 4Q185, might have been expected in the literature of a group that placed such emphasis on the study of and obedience to the Law as did the inhabitants of Qumran.

What can finally be said about the figures of Lady Wisdom and Dame Folly in the Qumran literature? The development of these figures in 4Q184, 185 and 525 takes place along lines already discernible in non-Qumran literature. This is particularly important in the case of Wisdom, whose separate identity is lost in the growing emphasis on Torah. If she ever was separate female divine figure, as can be argued from Proverbs 1-9, 1 Enoch 42, and the Wisdom of Solomon, she is no longer in Ben Sira, Baruch, and 4Q525. Equally important, this is not a "Qumranian" phenomenon, but occurs broadly in Second Temple literature. This would lead to the conclusion that these texts are not "sectarian," but are part of the general theological trends of Second Temple Judaism, within which we continually find the elevation of Torah. ${ }^{25}$ This trend continues to develop until it becomes "normative" in Judaism, as it remains until the present day. As for Dame

${ }^{24}$ Brooke, "The Wisdom of Matthew's Beatitudes," 36. See also É. Puech, “Un Hymne Essénien et les Béatitudes," RevQ 13 (1988) 57-88.

25 Thomas Tobin had already reached the conclusion, on other grounds, that 4Q185 was not a sectarian text. See T. Tobin, "4Q185 and Jewish Wisdom Literature," Of Scribes and Scrolls (eds H. Attridge, J.J. Collins, \& T. Tobin; College Theology Society Resources in Religion 5: Lanham, MD: University Press of America, 1990) 145-52. Puech likewise argues that 4Q525 is not a Qumran composition 
Folly, she undergoes a major change, from human figure (Proverbs 1-9), to semi-divine being (1 Enoch 42), to chthonic night demon (4Q184), but in all cases her portrayal continues an unfortunate emphasis on women's sexuality as sinful. This latter development takes exceptionally strong root in Christianity, with consequences felt until the present day. Thus we again see texts from Qumran not as isolated or unique, but as part of the general mix that we call Judaism in the Hellenistic and Roman periods.

("The Collection," 384); however, de Roo makes a case that 4Q525 was composed at Qumran. While the parallels she finds between 4Q525 and the so-called "sectarian" literature are interesting (see especially the parallel she draws between frag. 4, line 12, "the skilful dig her paths" and CD 6:25), it could be argued that 4Q525 affected the texts that she cites, rather than vice-versa (if Puech's date is accepted, this must be the case). The question of what makes a composition "sectarian," and how to determine what, if anything, was actually composed at Qumran, is not yet resolved. 